\title{
Sea Level Change in the Western James Bay Region of Subarctic Ontario: Emergent Land and Implications for Treaty No. 9
}

\author{
Leonard J.S. Tsuji, ${ }^{1}$ Amy Daradich, ${ }^{2}$ Natalya Gomez, ${ }^{3}$ Carling Hay ${ }^{4}$ and Jerry X. Mitrovica ${ }^{4}$
}

(Received 15 December 2014; accepted in revised form 20 July 2015)

\begin{abstract}
In 1905 and 1906, the Cree of the southwestern James Bay region signed Treaty No. 9 whereby they relinquished to the Canadian government their claim to the lands south of the Albany River (the northern boundary of the province of Ontario at the time). The official text of Treaty No. 9 made no mention of land submerged below water cover, and thus the Cree did not relinquish such regions at that time. By contrast, the Cree of the northwestern James Bay and southwestern Hudson Bay region who signed the 1929-30 Adhesions to Treaty No. 9 relinquished their claims to "land covered by water" for the area bounded on the south by the northerly limit of Treaty No. 9, as this clause was specifically included in the text of the adhesion. The issue of "land covered by water" is significant because the western James Bay region has been, and will continue to be, subject to sea level changes associated with ongoing adjustments due to the last ice age and modern global warming signals. In the absence of detailed maps, we used models of these processes, constrained by available geophysical and geodetic data sets, to retrodict shoreline changes and the rate of land emergence over the last two centuries within the boundaries specified by Treaty No. 9. We also project shoreline migration to the end of the 21 st century within the same region. The rate of land emergence since 1905 in the area south of the Albany River is estimated as $\sim 3.0 \mathrm{~km}^{2} / \mathrm{yr}$. Over the next century, land will continue to emerge in this region at a mean rate of $\sim 1.4 \mathrm{~km}^{2} / \mathrm{yr}$. This emergent land should be a subject of consideration within any comprehensive land claim put forward by the Cree; in this regard, it will be interesting to see how the Canadian judicial system and the Comprehensive Claims Branch handle the novel issue of emergent land.
\end{abstract}

Key words: global warming; glacial isostatic rebound; sea level change; western James Bay; subarctic Ontario; Cree; emergent land; Treaty No. 9

RÉSUMÉ. En 1905 et 1906, les Cris du sud-ouest de la région de la baie James ont signé le Traité no 9, par le biais duquel ils ont cédé au gouvernement du Canada leur droit de revendication des terres au sud de la rivière Albany (la limite nord de la province de l'Ontario à l'époque). Le texte officiel du Traité ${ }^{\circ} 9$ ne faisait aucune mention des terres submergées sous l'eau, si bien que les Cris n'ont pas renoncé à ces régions à ce moment-là. En revanche, les Cris du nord-ouest de la baie James et du sud-ouest de la baie d'Hudson qui ont signé les adhésions au Traité no 9 (1929-1930) ont renoncé à leurs revendications aux « terres recouvertes d'eau » dans la zone délimitée au sud par la limite nord du Traité no 9, puisque cette clause était expressément incluse dans le texte de l'adhésion. La question des « terres recouvertes d'eau » est importante parce que l'ouest de la région de la baie James a été et continuera d'être assujettie aux variations du niveau de la mer liées aux ajustements continus découlant de la dernière période glaciaire et des récents signes de réchauffement planétaire. En l'absence de cartes détaillées, nous avons utilisé des modèles de ces processus, limités par les ensembles de données géophysiques et géodésiques disponibles, pour déterminer de façon rétrospective les changements du littoral et le taux d'émergence des terres au cours des deux derniers siècles dans les limites précisées dans le Traité $n^{\circ} 9$. Nous faisons également une projection de la migration du littoral jusqu'à la fin du XXI siècle dans cette même région. Le taux d'émergence des terres depuis 1905 dans la région au sud de la rivière Albany est estimé à $\sim 3,0 \mathrm{~km}^{2} /$ année. Au cours du prochain siècle, les terres continueront d'émerger dans cette région au taux moyen de $\sim 1,4 \mathrm{~km}^{2} /$ année. Ces terres émergées devraient être prises en compte dans toute revendication territoriale globale présentée par les Cris. À cet égard, il sera intéressant de voir comment le système judiciaire canadien et la Direction générale des revendications globales traiteront cette nouvelle question des terres émergées.

Mots clés : réchauffement planétaire; relèvement isostatique glaciaire; variations du niveau de la mer; ouest de la baie James; Ontario subarctique; Cris; terres émergées; Traité $\mathrm{n}^{\circ} 9$

Traduit pour la revue Arctic par Nicole Giguère.

\footnotetext{
${ }^{1}$ Health Studies, and the Department of Physical and Environmental Sciences, University of Toronto Scarborough, Toronto, Ontario M1C 1A4, Canada; leonard.tsuji@utoronto.ca

${ }^{2}$ Department of Earth Sciences, University of Ottawa, Ottawa, Ontario K1N 6N5, Canada

${ }^{3}$ Department of Earth and Planetary Sciences, McGill University, Montreal, Quebec H3A 0E8, Canada

${ }^{4}$ Department of Earth and Planetary Sciences, Harvard University, Cambridge, Massachusetts 02138, USA

(C) The Arctic Institute of North America
} 


\section{INTRODUCTION}

At confederation in 1867, the Province of Canada was divided into the provinces of Ontario and Quebec; these two provinces, along with New Brunswick and Nova Scotia, formed the Dominion of Canada (Dean, 1969; Archives of Ontario, 2008; Fig. 1a). In 1870, an Imperial (British) Order-in-Council confirmed the acquisition and admittance of Rupert's Land and the North-Western Territory into the Dominion of Canada (Rupert's Land and North-Western Territory - Enactment No. 3, 1870), as the British North America Act (1867) had made provisions for this eventuality. The landmass of Ontario at confederation was smaller than present-day Ontario, and in 1874 the Ontarian boundaries were provisionally moved west and north to increase its size (Dean, 1969; Archives of Ontario, 2008; Fig. 1b). In 1889 , the Albany River became the northern boundary of Ontario (Dean, 1969; Archives of Ontario, 2008; Fig. 1c). As this northern extension was acquired at the expense of the District of Keewatin, Northwest Territories (formerly Rupert's Land and North-Western Territory) - and this land had not been surrendered by treaty - a treaty with the Indians who occupied this area would be required in the near future. Treaties between the Indians and the Dominion of Canada were required because the British Crown recognized Indian land rights in North America (The Royal Proclamation of 1763; Henry, 2006).

In 1905, a field team consisting of commissioners from both Ontario (Daniel G. MacMartin) and the Canadian government (Duncan C. Scott and Samuel Stewart) was assembled and entrusted with the task of traveling down the Albany River and entering into a treaty (Treaty No. 9, 1905-06) with Indian groups occupying the region south of the Albany River (Scott et al., 1905). As not all the Indian groups south of the Albany River agreed to enter into Treaty No. 9 in 1905, a second trip was required in 1906. The text of Treaty No. 9 (1905-06) specified the lands to which the Indians relinquished claim by signing the treaty, as follows:

the said Indians [Cree, Ojibwa and others] do hereby cede, release, surrender and yield up to the government of the Dominion of Canada, for His Majesty the King and His successors for ever, all their rights titles and privileges whatsoever, to the lands included within the following limits, that is to say: That portion or tract of land lying and being in the province of Ontario, bounded on the south by the height of land and the northern boundaries of the territory ceded by the RobinsonSuperior Treaty of 1850, and the Robinson-Huron Treaty of 1850, and bounded on the east and north by the boundaries of the said province of Ontario as defined by law, and on the west by a part of the eastern boundary of the territory ceded by the Northwest Angle Treaty No. 3 ; the said land containing an area of ninety thousand square miles, more or less.
A "blanket" land clause that was standard procedure for most of the previous numbered treaties (e.g., Treaty No. 4, 1874; Treaty No. 8, 1899) was also included in Treaty No. 9. This land clause read as follows:

And also, the said Indian rights, titles and privileges whatsoever to all other lands wherever situated in Ontario, Quebec, Manitoba, the District of Keewatin, or in any other portion of the Dominion of Canada.

It should be emphasized that no mention was made of "land covered by water" in the official text of Treaty No. 9 and that the Canadian government recognizes that only the text in any treaty is binding (but see Macklem, 1997 and Long, 1993):

the Government [of Canada] cannot admit [the Indians'] claim to any thing which is not set forth in the treaty [with specific reference to Treaties 1 and 2]...which treaty is binding alike upon the Government and upon the Indians....

(Honourable Privy Council, 1875)

By contrast, the Adhesions to Treaty No. 9 (1931) were signed by "Indians" who lived in the area north of the Albany River (see Fig. 2a); this agreement included a "land covered by water" clause:

[the said Indians residing north of the area included in Treaty No. 9] do hereby cede, release, surrender and yield up to the Government of the Dominion of Canada for His Majesty the King and His Successors forever, all our rights, titles and privileges whatsoever in all that tract of land, and land covered by water in the Province of Ontario, comprising part of the District of Kenora (Patricia Portion) containing one hundred and twenty-eight thousand three hundred and twenty square miles, more or less, being bounded on the South by the Northerly limit of Treaty Number Nine; on the West by Easterly limits of Treaties Numbers Three and Five, and the boundary between the Provinces of Ontario and Manitoba; on the North by the waters of Hudson Bay, and on the East by the waters of James Bay and including all islands, islets and rocks, waters and land covered by water [our emphasis] within the said limits, and also all the said Indian rights, titles and privileges whatsoever to all other lands and lands covered by water [our emphasis], wherever situated in the Dominion of Canada.

(Adhesions to Treaty No. 9, 1931)

Although the importance of the absence of a "land covered by water" clause in Treaty No. 9 has been recognized by the regional tribal organization, Nishnawbe-Aski Nation, which includes the First Nations of Treaty No. 9 (the western James Bay Cree) (Hookimaw-Witt, 1997), a formal legal case has yet to be filed (Comprehensive Claims 
(a)

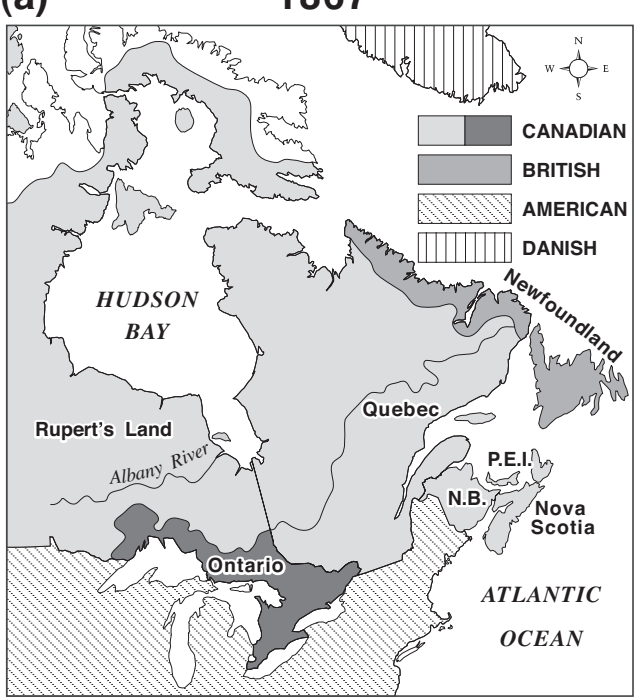

(b)

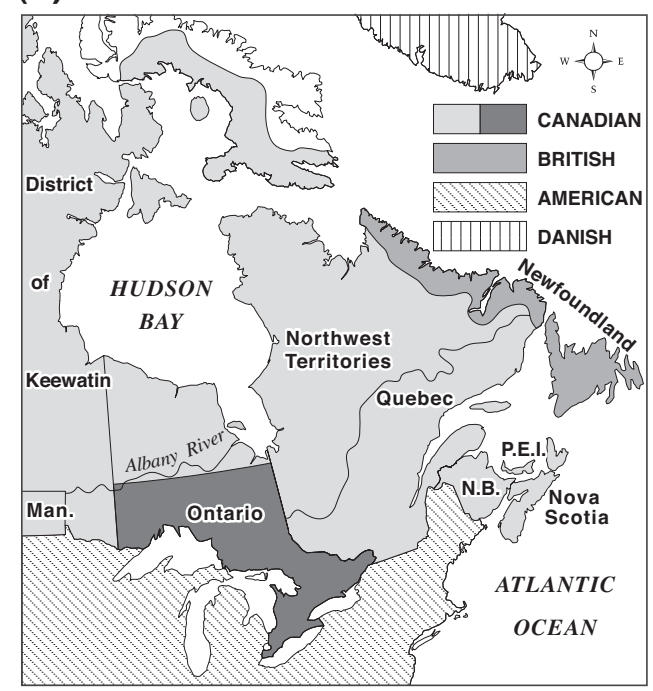

(c)

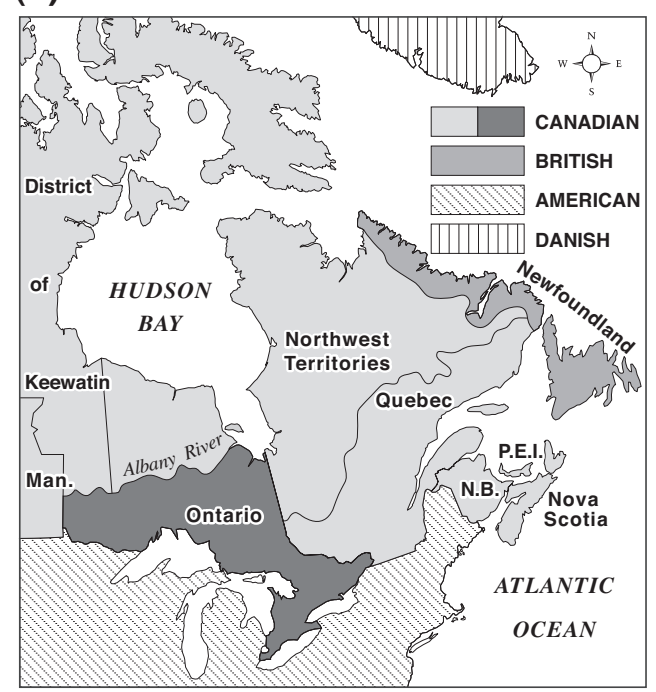

FIG. 1. The boundaries of Ontario (a) at Confederation in 1867; (b) in 1874; and (c) in 1889. Maps modified from Dean (1969) and the Archives of Ontario (2008).

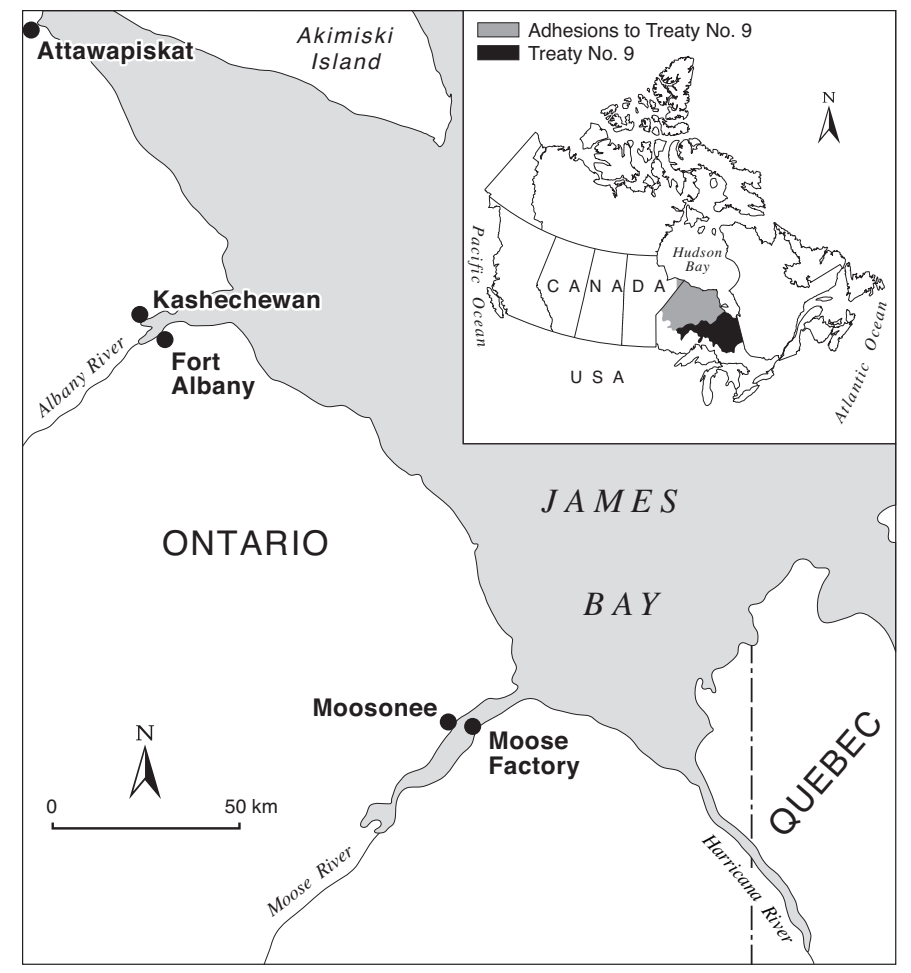

FIG. 2. The study area, with inset outlining the boundaries of lands covered by Treaty No. 9 (1905-06) and the adhesions to the treaty made in 1929-30.

Branch, 2007). Nevertheless, the "land covered by water" clause gains even greater significance when emergent land as related to sea level change in the James Bay region is taken into account.

The earth is currently in an interglacial period, yet the James Bay region is subject to ongoing adjustment in consequence of the ice age that ended about 8000 years ago. Specifically, this region, which was once covered by an ice sheet that reached a thickness of 3-4 km at the peak of the last glacial cycle, is currently experiencing a postglacial rebound of the solid crust at rates of approximately $1 \mathrm{~cm} / \mathrm{yr}$ (Mitrovica et al., 2000). This postglacial rebound gives rise to a land emergence, or alternatively a sea level fall, that is accompanied by shoreline migration. This migration has been active since the region became ice-free and is responsible for the raised late Holocene beach terraces that pervade the region (Martini, 1981a). In addition to this ongoing ice age signal, the region has also been subject, over the last century, to sea level changes associated with global warming. There is general consensus of a globally averaged rise due to global warming of approximately $1-2 \mathrm{~mm} / \mathrm{yr}$ over this period (Church and White, 2011), but this sea level variation was highly variable geographically (Milne et al., 2009; Slangen et al., 2012).

In an earlier paper (Tsuji et al., 2009), sea level changes in the James Bay region over the next millennium were predicted using a combination of numerical models of the ongoing sea level change due to the ice age and projections of the future global warming signal appearing in the Fourth Assessment Report of the Intergovernmental Panel on 
Climate Change (IPCC, 2007). Our goal in that paper was to investigate possible future development of land bridges connecting current islands in James Bay with the mainland. In the present paper, we turn our attention to sea level changes over the last two centuries and during the next century. In particular, we retrodict past shoreline locations in the western James Bay area based on boundaries specified by Treaty No. 9 (1905-06) to determine the rate of land emergence (i.e., the appearance of land formerly covered by water) since 1905 and from the present to the end of the 21 st century. We also estimate the migration of shorelines in western James Bay during the century prior to 1905 . No significant global change signal was active over this period, and thus the estimate provides a baseline for understanding the impact of global warming on land emergence during the 20th and 21st centuries. Our calculations are based on a numerical model of the ice age process, calibrated to fit geological and geodetic data sets, and a regional signal due to global warming.

\section{METHODS}

Computing the response of the earth to the late Pleistocene glacial cycles (glacial isostatic adjustment; henceforth GIA) requires models of both the space-time history of the ice cover and the viscoelastic structure of the earth. In this paper we adopt a modified form of the ICE-5G ice history (see below) and the VM2 viscosity model (Peltier, 2004). The VM2 model is characterized by an elastic lithosphere $\sim 90 \mathrm{~km}$ thick, and a mantle viscosity that increases from $\sim 5 \times 10^{20} \mathrm{~Pa}$ s in the upper mantle to $\sim 2-3 \times 10^{21} \mathrm{~Pa} \mathrm{~s}$ in the deep mantle. The ICE-5G and VM2 models are coupled in the sense that they have been derived together by iteratively improving both models to yield fits to globally distributed Late Holocene sea level data. While each of the models has significant uncertainty, their combination is constrained to fit these relative sea level histories. It would not be expected that the combined ICE-5G/VM2 model would provide an optimal fit to data at all locations. In the next section, we fine-tune the ice-history component of the combined model so that predictions based upon it are consistent with radial crustal deformation rates in the James Bay region as measured through surveying with the Global Positioning System. With this combined ice-earth model in hand, we calculate changes in topography (or sea level) since the Last Interglacial ( 120 kyr ago). This calculation is based on a gravitationally self-consistent postglacial sea level theory that accounts for the deformational, gravitational, and rotational effects of the changing ice + water load (Kendall et al., 2005).

A regional sea level signal associated with global warming is next added to the computed ice age signal. In this study, in order to sample a broad range of global warming signals, we present results from 1800 to the end of the 21 st century. For the period $1800-1905$, we assume that there is no global change signal. A probabilistic (Kalman smoother) analysis of a widely distributed network of tide gauge records has estimated globally averaged sea level change across the 20th century due to global warming (Hay et al., 2015). We have used the full reconstruction of sea level generated from this recent analysis to estimate the mean rate of sea level change within the James Bay region from 1905 to 1990. This value, $1.57 \pm 0.28 \mathrm{~mm} / \mathrm{yr}$ (95\% confidence interval), accounts for the net signal due to recent ice volume changes, dynamic ocean variability, and thermosteric effects. (See Gough, 1998, for a discussion of the thermosteric signal in the James Bay and Hudson Bay regions.) Finally, for the period from 1990 to the end of the current century, we adopt two estimates of projected global mean sea level changeRCP2.6 (4.5 mm/yr) and RCP8.5 (8 mm/yr) - cited in the 5th Assessment Report of the Intergovernmental Panel on Climate Change (Church et al., 2013: Section 13.8).

Finally, the total sea level change associated with the ice age and modern global warming signals are combined with a dataset of present-day topography in order to track past changes in topography. For this purpose, we used presentday topography fields for James Bay from the Canadian Digital Elevation Model 0.75 arc second grid (NRC, 2013). Shorelines were defined as the contour of zero topography (i.e., locations where the sea surface and the crust were equal in height), and so their migration was tracked once the time history of topography was established. Changes in shoreline geometry since 1905 , and in particular the areal extent covered by the associated land emergence over the area covered by Treaty No. 9 (1905-06; See Fig. 2), will be the focus of our calculations and discussions below.

\section{RESULTS}

Figure 3 shows estimates of the present day rate of change of crustal elevation, with uncertainty, determined by GPS surveys at a suite of sites in the James Bay region (Canadian Base Network [NRC, 2003]; black dots), as well as predictions based on the ICE-5G/VM2 model of the GIA process (blue dots). The location of the sites is shown in the inset. While the model accurately predicts the geographic variability in the crustal uplift signal, it overestimates the magnitude of the ice age signal. We applied a series of uniform scalings to the ICE-5G ice thickness history in the James Bay region and found, accounting for errors in the GPS estimates, that a scaling of 0.93 yields a best RMS fit to the GPS rates (green dots). We adopt this modified version of the ICE-5G model in our predictions of the ongoing sea level change due to GIA. We note that this modified GIA model still overestimates the crustal uplift rate at Moosonee (site 1), the site closest to our region of interest, by $\sim 10 \%$. It is therefore possible that in the analysis below we overestimate the ongoing sea level change due to the ice age by the same amount. However, given the possibility of error in the individual GPS rates, we believe that the choice of scaling should be based on the set of all James Bay GPS observations, rather than the estimated uplift rate at a specific site. 


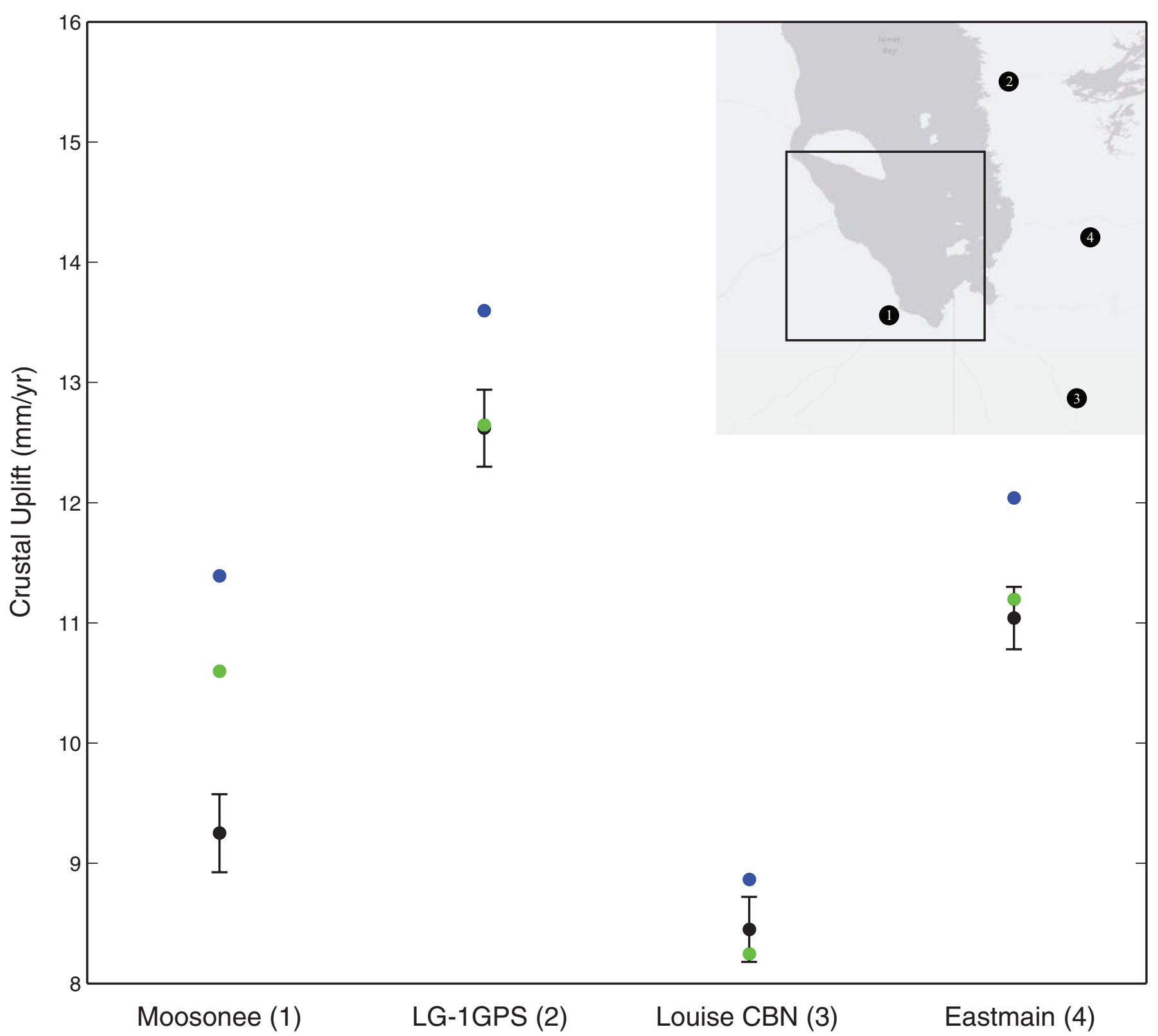

FIG. 3. Predicted present-day rates of crustal uplift due to the ice age at sites in the James Bay region (see inset; box outlines region shown in Fig. 2), together with observational constraints obtained from GPS surveying (Canadian Base Network [NRC, 2003]; black dots). Blue dots show predictions for the ICE-5G/ VM2 model of GIA (Peltier, 2004), while green dots show a prediction in which ice thicknesses in the James Bay region over the last glacial cycle are scaled by a factor of 0.93 (see text). The time period we consider in this article (1800-2100) is sufficiently short that the predicted rates of uplift due to GIA may be assumed constant.

Figure 4 shows the present day rate of change of sea level over the James Bay region associated with ongoing adjustment due to the ice age, computed using our GIA model. The sea level change in this area is dominated by postglacial uplift of the crust at a rate of $\sim 1 \mathrm{~cm} / \mathrm{yr}$ (Fig. 3; see also Gough and Robinson, 2000), and the result is a broad, cumulative sea level fall of $\sim 1 \mathrm{~m}$ per century. Thus, ice age effects dominate the sea level rise induced over the region by global warming during our period of interest, although the magnitude of 21st century sea level rise estimated in the RCP 8.5 projection $(8.0 \mathrm{~mm} / \mathrm{yr})$ is comparable in magnitude. We note that a tide gauge record at Churchill, Manitoba, has a mean rate of $\sim 12 \mathrm{~mm} / \mathrm{yr}$ from 1940 to 1990 (Tushingham,
1992; Gough and Robinson, 2000), which is consistent with the sum of the ice age signal in Figure $4(10.2 \mathrm{~mm} / \mathrm{yr})$ and the regional global change signal noted above $(1.57 \mathrm{~mm} / \mathrm{yr})$.

As an illustration of the results, Figure 5 shows the geographic extent of land that has emerged in the James Bay region since 1800 , computed by combining the ice age prediction with the global warming signal discussed above $(0 \mathrm{~mm} / \mathrm{yr}$ for $1800-1905$ and $1.2 \mathrm{~mm} / \mathrm{yr}$ from 1905 to present). Over this time period, land emergence took place at nearly all sites along the James Bay shoreline, with particularly significant shoreline migration at the mouths of the Albany, Moose, and Harricana Rivers. For the region covered by Treaty No. 9 (1905-06), which is bounded on the 


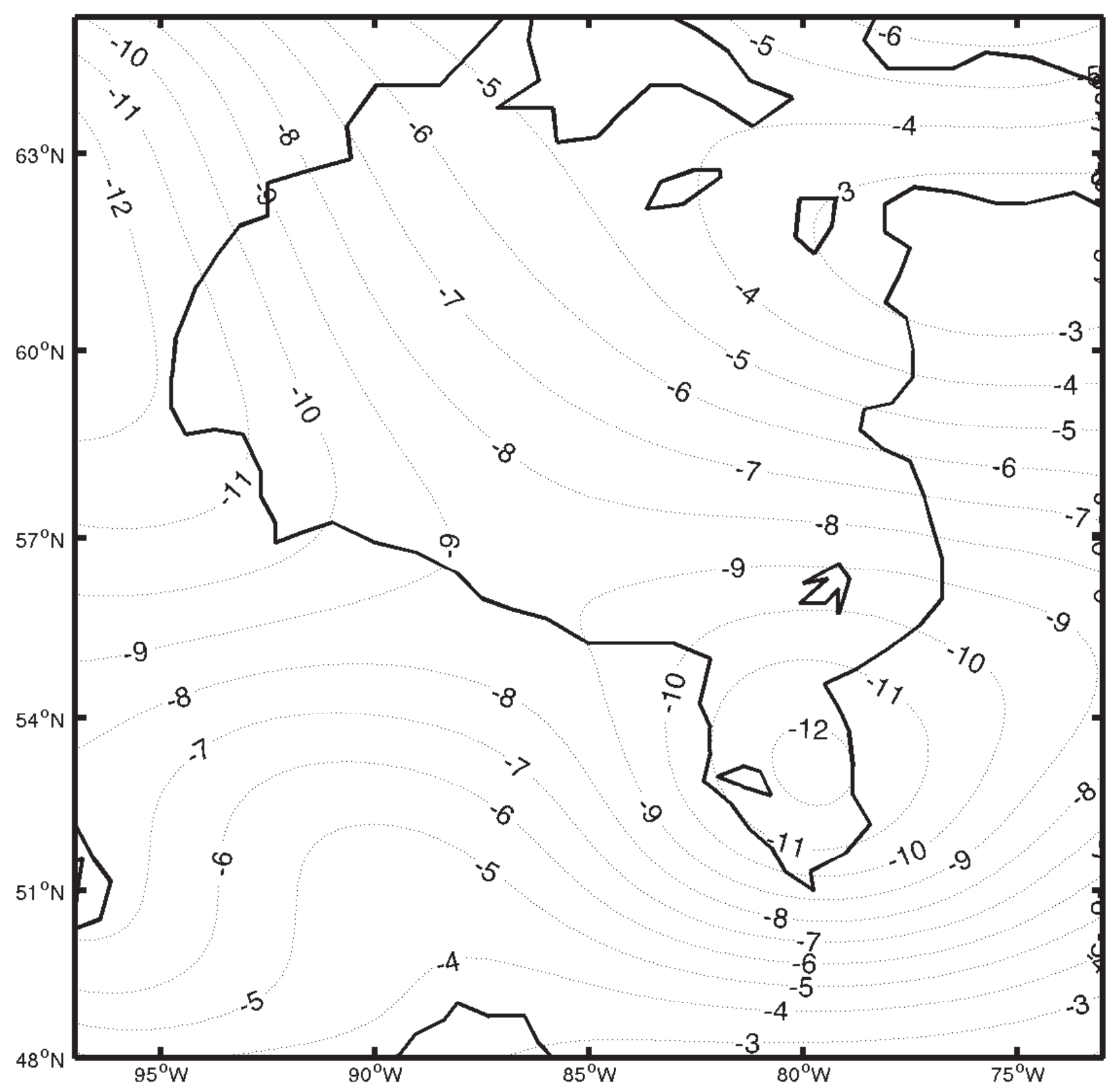

FIG. 4. Predicted present-day rate of sea level change in the James Bay region due to the ice age based on the VM2 viscosity model (Peltier, 2004) and our modified form of the ICE-5G ice history (see text). All contoured values (in mm/yr) are negative. The time period we consider (1800-2100) is sufficiently short that the rate of predicted sea level change due to GIA may be assumed to be constant.

north by the Albany River, on the west and south by the shoreline of James Bay, and on the east by the OntarioQuebec border (Fig. 2), we predicted the total rate of land emergence for three time periods. For $1800-1905$, the rate is $3.6 \mathrm{~km}^{2} / \mathrm{yr}$; for $1905-2014,3.0 \pm 0.1 \mathrm{~km}^{2} / \mathrm{yr}(95 \%$ confidence interval); and for $2014-2100,2.0 \mathrm{~km}^{2} / \mathrm{yr}$ using the RCP2.6 sea level projection, or $0.8 \mathrm{~km}^{2} / \mathrm{yr}$ using the RCP 8.5 projection. Thus, the total land emergence we retrodict for $1905-2014$ is $331 \pm 12 \mathrm{~km}^{2}$ (95\% confidence interval), and we project that $70-170 \mathrm{~km}^{2}$ of land will emerge over the period 2014-2100.

\section{DISCUSSION}

Extensive tracts of land south of the Albany River have emerged over the last 110 years. Our geophysical model of ice age dynamics is subject to some uncertainty, although the results in Figure 3 indicate that our GIA model yields predictions that are consistent to a level of $10 \%$ with available GPS estimates of crustal uplift rates in the James Bay region. Geomorphological and hydrological phenomena also introduce some uncertainty regarding the areal extent of emergent land. For example, sedimentary processes tend to add material to the western James Bay shoreline (Martini 


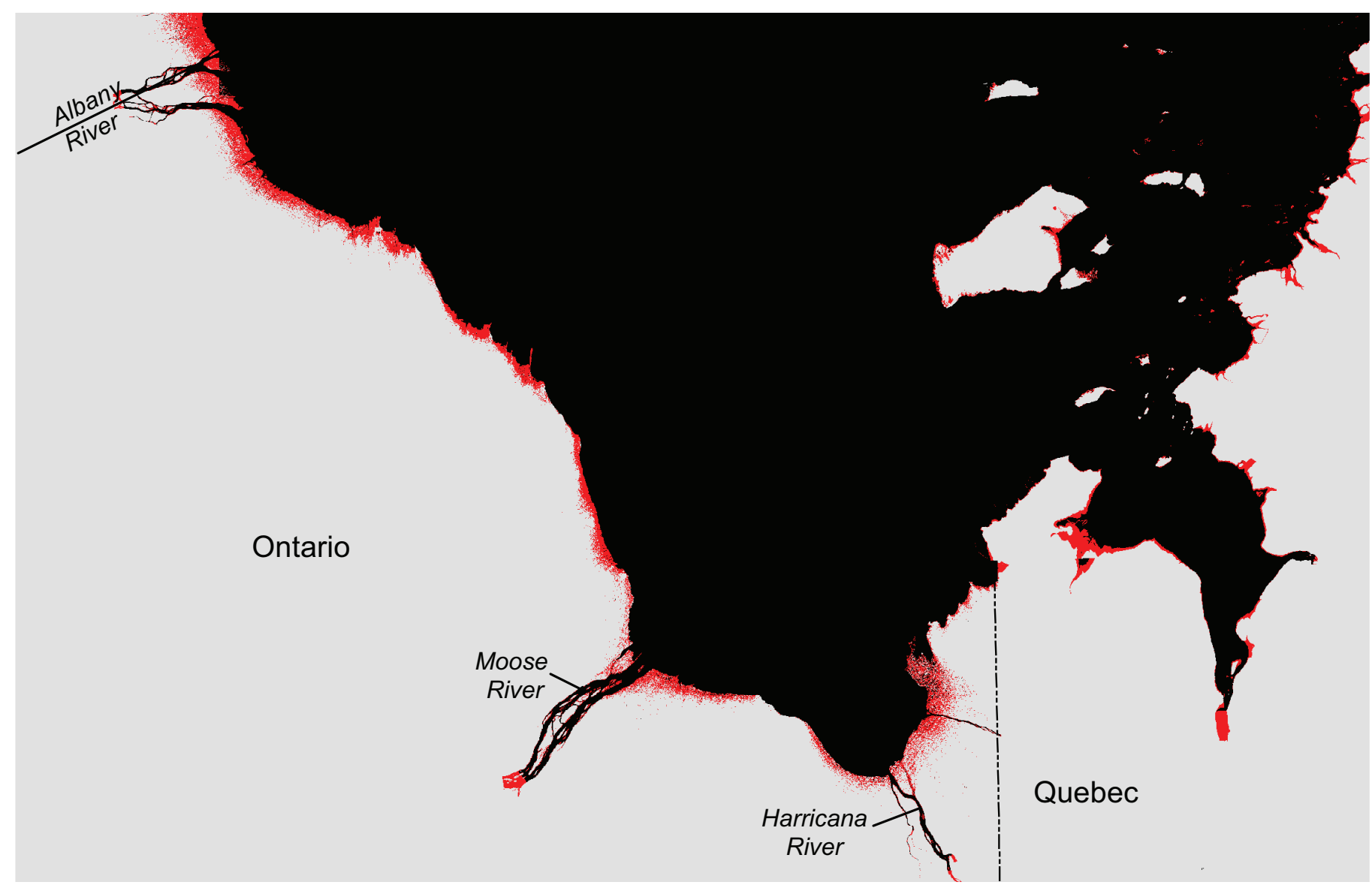

FIG. 5. Predicted migration of the shoreline in the James Bay region since 1800 computed by combining the GIA signal in Figure 4 (after multiplying by 2014 $1800=214$ years $)$ with an estimate of the regional sea level rise over the last century due to regional change $(1.57 \pm 0.28 \mathrm{~mm} / \mathrm{yr}) \mathrm{based}$ on a statistical analysis of regionally distributed tide gauge records.

and Glooschenko, 1983-84; Poehlman, 1996), while the lifting of ice blocks during the spring thaw season removes sediments, and ice-walled channels canalize tidal currents and erode mud flats (Martini, 1981b). Moreover, longterm variability in runoff into James Bay and Hudson Bay, as well as in groundwater discharge, will impact regional trends in sea level (Gough et al., 2005). Nevertheless, land emergence in Hudson Bay and James Bay is a wellstudied geophysical phenomenon (Walcott, 1972), and it is well documented in the indigenous knowledge of the western James Bay region (McDonald et al., 1997). Indeed, the rates of emergence are sufficient that observations of the ongoing phenomenon are common amongst First Nations people of the region (e.g., former Deputy Chief Charlie Cheechoo of the Moose Cree First Nation, pers. comm. 2008).

Given the extent of emergent land in southern James Bay over the past century, the continued land emergence over the next century and beyond, and the well-documented mineral wealth in the region (AMEC, 2004; Koven, 2007; Larmour, 2007), the economic implications associated with disputes over land rights are substantial. The First Nations of the western James Bay region are not opposed to controlled resource development per se, but they have argued that development should take place within a framework in which the First Nations people also benefit (Chief Andrew
Solomon of Fort Albany First Nation, pers. comm. 2009). The well-being of the Cree is also closely tied to that of the environment (Hookimaw-Witt, 1997), and therefore land issues in the western James Bay region are of great importance beyond the monetary. Since "land covered by water" (i.e., emergent land) was never surrendered through the signing of Treaty No. 9 (1905-06) for the land south of the Albany River, the western James Bay Cree will likely be submitting a land claim that specifically treats the issue of emergent land (Chief Andrew Solomon of Fort Albany First Nation, pers. comm. 2009).

We are unaware of any treaty land claims based on the issue of emergent land and believe this is a new area of endeavour with respect to land claims in Canada. In Canada, there exists the common law concept of Aboriginal rights and title; existing Aboriginal rights were affirmed in the Canadian Constitution Act (1982) under section 35 (1) (INAC, 1993). In addition, the Supreme Court of Canada's Calder decision in 1973 acknowledged the existence of Aboriginal title in Canadian law (Hurley, 2000), resulting in the first policy statement on land claims (INAC, 1993; Comprehensive Claims Branch, 2007). Canadian policy divides land claims into two basic categories: comprehensive and specific. Comprehensive claims are based on the assertion that Aboriginal rights and title to land and 
resources were never relinquished through treaty or other legal means, while specific claims refer to alleged misadministration of Indian assets or the non-fulfillment of government responsibilities related to treaties (INAC, 1993; Comprehensive Claims Branch, 2007). Clearly, emergent land would fall under the comprehensive land claim category since this type of land was not considered in Treaty No. 9 (1905-06).

The primary purpose of the comprehensive claim process is to reach a negotiated agreement (i.e., a modern treaty) whereby undefined rights of Aboriginal peoples are exchanged for a specifically defined package of rights and benefits (including lands and resources) that is constitutionally protected (INAC, 1993; Comprehensive Claims Branch, 2007). Thus, it is unclear how the Canadian judicial system and the Comprehensive Claims Branch will handle the novel issue of emergent land in the western James Bay region, with respect to Treaty No. 9. In this regard, the predictions described herein may serve as scientific input into any upcoming negotiations. More generally, these predictions emphasize that environmental change, whether natural (i.e., ongoing ice age effects) or anthropogenic in origin (global warming), are realities that should inform discussions between First Nations people, the government, and the general public.

\section{ACKNOWLEDGEMENTS}

We acknowledge support from the following sources: the Social Sciences and Humanities Research Council of Canada and the Canadian Institutes of Health Research (IPH \#143068) (L.J.S. Tsuji); the National Science and Engineering Research Council of Canada, and Harvard University (N. Gomez, C. Hay, J.X. Mitrovica); and the M. Hildred Blewett Fellowship of the American Physical Society, www.aps.org (A. Daradich). We thank W.A. Gough and two anonymous reviewers for their comments.

\section{REFERENCES}

Adhesions to Treaty No. 9. 1931. Chapter 7: The James Bay Treaty - Treaty No. 9 (Made in 1905 and 1906) and Adhesions Made in 1929 and 1930.

http://www.aadnc-aandc.gc.ca/eng/1100100028863/110010002 8864\#chp7

AMEC. 2004. Victor Diamond Mine comprehensive study environmental assessment main report. Mississauga, Ontario: DeBeers Canada and AMEC Consulting.

Archives of Ontario. 2008. The evolution of Ontario's boundaries $1774-1912$.

http://www.archives.gov.on.ca/en/maps/ontario-boundaries. aspx

Church, J.A., and White, N.J. 2011. Sea-level rise from the late 19th to the early 21st century. Surveys in Geophysics 32(4):585-602.

http://dx.doi.org/10.1007/s10712-011-9119-1
Church, J.A., Clark, P.U., Cazenave, A., Gregory, J.M., Jevrejeva, S., Levermann, A., Merrifield, M.A., et al. 2013. Sea level change. In: Stocker, T.F., Qin, D., Plattner, G.-K., Tignor, M.M.B., Allen, S.K., Boschung, J., Nauels, A., Xia, Y., Bex, V., and Midgley, P.M., eds. Climate change 2013: The physical science basis. Contribution of Working Group I to the Fifth Assessment Report of the Intergovernmental Panel on Climate Change. Cambridge: Cambridge University Press.

http://www.ipcc.ch/pdf/assessment-report/ar5/wg1/WG1AR5_ Chapter13_FINAL.pdf

Comprehensive Claims Branch. 2007. General briefing note on the comprehensive land claims policy of Canada and the status of claims. Ottawa: Comprehensive Claims Branch, Claims and Indian Government Sector, Indian Affairs and Northern Development. 35 p.

http://epe.lac-bac.gc.ca/100/200/301/inac-ainc/general_ briefing_note-e/gbn_e.pdf

Dean, W.G. 1969. Economic atlas of Ontario. Toronto, Ontario: University of Toronto Press.

Gough, W.A. 1998. Projections of sea-level change in Hudson and James Bays, Canada, due to global warming. Arctic and Alpine Research 30(1):84-88.

http://dx.doi.org/10.2307/1551748

Gough, W.A., and Robinson, C.A. 2000. Sea-level variation in Hudson Bay, Canada, from tide-gauge data. Arctic, Antarctic, and Alpine Research 32(3):331-335. http://dx.doi.org/10.2307/1552532

Gough, W.A., Robinson, C., and Hosseinian, R. 2005. The influence of James Bay river discharge on Churchill, Manitoba sea level. Polar Geography 29(3):213-223.

http://dx.doi.org/10.1080/789610202

Hay, C.C., Morrow, E., Kopp, R.E., and Mitrovica, J.X. 2015. Probabilistic reanalysis of twentieth-century sea-level rise. Nature 517:481 - 484 .

http://dx.doi.org/10.1038/nature14093

Henry, J. 2006. The Proclamation of 1763: A model for the establishment of treaties.

http://www.lac-bac.gc.ca/publications/002/015002-2010-e. html

Honourable Privy Council. 1875. A report of a Committee of the Honourable Privy Council, approved by His Excellency the Governor General in Council on the 30th April, 1875.

https://www.aadnc-aandc.gc.ca/eng/1100100028664/11001000 28665

Hookimaw-Witt, J. 1997. Keenebonanoh keemoshominook kaeshe peemishikhik odaskiwakh [We stand on the graves of our ancestors] Native interpretations of Treaty \#9 with Attawapiskat Elders. MA thesis, Trent University, Peterborough, Ontario.

http://www.collectionscanada.gc.ca/obj/s4/f2/dsk2/tape15/ PQDD_0016/MQ30219.pdf

Hurley, M.C. 2000. Aboriginal title: The Supreme Court of Canada decision in Delgamuukw v. British Columbia. Ottawa: Parliamentary Information and Research Service, Library of Parliament. 34 p. 
IPCC (Intergovernmental Panel on Climate Change). 2007. Climate change 2007: Synthesis report. Contribution of Working Groups I, II and III to the Fourth Assessment Report of the Intergovernmental Panel on Climate Change. Edited by the Core Writing Team, R.K. Pachauri and A. Reisinger. Geneva, Switzerland: IPCC. 104 p.

INAC (Indian and Northern Affairs Canada). 1993. Federal policy for the settlement of Native claims. Ottawa: INAC. 31 p.

Kendall, R.A., Mitrovica, J.X., and Milne, G.A. 2005. On postglacial sea level: II. Numerical formulation and comparative results on spherically symmetric models. Geophysical Journal International 161(3):679-706. http://dx.doi.org/10.1111/j.1365-246X.2005.02553.x

Koven, P. 2007. Is this Voisey's Bay II? Financial Post, October 13.

http://www.financialpost.com/story.html?id=84a8d38f-5a09450c-81ee-185441db3305\&p=1

Larmour, A. 2007. Shooting for double eagle. Northern Ontario Business, October 15.

http://www.northernontariobusiness.com/Industry-News/ mining/Shooting-for-double-eagle.aspx

Long, J.S. 1993. "The government is asking for your land": The treaty made in 1905 at Fort Albany according to Cree oral tradition. $159 \mathrm{p}$.

https://faculty.nipissingu.ca/johnlo/John Long/treaty\%20 made\%20in\%201905\%20at\%20fort\%20albany.pdf

Macklem, P. 1997. The impact of Treaty 9 on natural resource development in northern Ontario. In: Asch, M., ed. Aboriginal and treaty rights in Canada: Essays on law, equality, and respect for difference. Vancouver: UBC Press. 97-134.

Martini, I.P. 1981a. Morphology and sediments of the emergent Ontario coast of James Bay, Canada. Geografiska Annaler 63(1/2):81-94.

http://dx.doi.org/10.2307/520567

- 1981b. Ice effect on erosion and sedimentation on the Ontario shores of James Bay, Canada. Zeitschrift für Geomorphologie 25:1-16.

Martini, I.P., and Glooschenko, W.A. 1983-84. Emergent coasts of Akimiski Island, James Bay, Northwestern Territories, Canada: Geology, geomorphology, and vegetation. Sedimentary Geology 37(4):229-250.

http://dx.doi.org/10.1016/0037-0738 (84)90016-2

McDonald, M., Arragutainaq, L., and Novalinga, Z., compilers. 1997. Voices from the Bay: Traditional ecological knowledge of the Inuit and Cree in the Hudson Bay bioregion. Sanikiluaq, Nunavut: Canadian Arctic Resources Committee and the Environmental Committee of Municipality of Sanikiluaq. $98 \mathrm{p}$.

Milne, G.A., Gehrels, R., Hughes, C.W., and Tamisiea, M.E. 2009. Identifying the causes of sea-level change. Nature Geoscience $2: 471-478$. http://dx.doi.org/10.1038/ngeo544

Mitrovica, J.X., Forte, A.M., and Simons, M. 2000. A reappraisal of postglacial decay times from Richmond Gulf and James Bay, Canada. Geophysics Journal International 142(3):783-800. http://dx.doi.org/10.1046/j.1365-246x.2000.00199.x
NRC (Natural Resources Canada). 2003. Canadian Geodetic Network - Canadian Base Network. http:/geogratis.gc.ca/api/en/nrcan-rncan/ess-sst/09fd34ee22eb-431b-b4a6-99a828199f14.html

- 2012. Canadian Digital Elevation Model Mosaic. Ottawa: NRC.

http:/geogratis.gc.ca/api/en/nrcan-rncan/ess-sst/C40ACFBAC722-4BE1-862E-146B80BE738E.html

Peltier, W.R. 2004. Global glacial isostasy and the surface of the ice-age Earth: The ICE-5G (VM2) model and GRACE. Annual Review of Earth and Planetary Sciences 32:111-149. http://dx.doi.org/10.1146/annurev.earth.32.082503.144359

Poehlman, T. 1996. Bar sedimentation at the head of the estuary of the Moose River, northern Ontario. MS thesis, University of Guelph, Guelph, Ontario. 278 p.

Rupert's Land and North-Western Territory - Enactment No. 3. 1870. Part 1.

http:/canada.justice.gc.ca/eng/rp-pr/csj-sjc/constitution/ lawreg-loireg/p1t31.html

Scott, D.C., Stewart, S., and MacMartin, D.G. 1905. Chapter 1: James Bay Treaty - Treaty No. 9 - November 6, 1905. Letter to The Honourable Superintendent General of Indian Affairs, Ottawa.

http://www.aadnc-aandc.gc.ca/eng/1100100028863/110010002 8864\#chp1

Slangen, A.B.A., Katsman, C.A., van de Wal, R.S.W., Vermeersen, L.L.A., and Riva, R.E.M. 2012. Towards regional projections of twenty-first century sea-level change based on IPCC SRES scenarios. Climate Dynamics 38(5):1191-1209.

http://dx.doi.org/10.1007/s00382-011-1057-6

Treaty No. 4. 1874. Treaty 4 between Her Majesty the Queen and the Cree and Saulteaux tribes of Indians at the Qu'appelle and Fort Ellice.

http://www.aadnc-aandc.gc.ca/eng/1100100028689/ 1100100028690

Treaty No. 8. 1899. Treaty No. 8. Made June 21, 1899 and adhesions, reports, etc.

http://www.treaty8.ca/documents/Treaty8_1899.pdf

Treaty No. 9. 1905-06. The James Bay Treaty - Treaty No. 9 (Made in 1905 and 1906) and Adhesions made in 1929 and 1930.

http://www.aadnc-aandc.gc.ca/eng/1100100028863/110010002 8864

Tsuji, L.J.S., Gomez, N., Mitrovica, J.X., and Kendall, R. 2009. Post-glacial isostatic adjustment and global warming in Subarctic Canada: Implications for islands of the James Bay region. Arctic 62(4):458-467.

http://dx.doi.org/10.14430/arctic176

Tushingham, A.M. 1992. Observations of postglacial uplift at Churchill, Manitoba. Canadian Journal of Earth Sciences 29(11):2418-2425.

http://dx.doi.org/10.1139/e92-189

Walcott, R.I. 1972. Late Quaternary vertical movements in eastern North America: Quantitative evidence of glacio-isostatic rebound. Reviews of Geophysics 10(4):849-884.

http://dx.doi.org/10.1029/RG010i004p0084 